\title{
PENGARUH FAKTOR HIDRODINAMIKA TERHADAP SEBARAN LIMBAH AIR PANAS DI LAUT
}

\author{
Oleh \\ Dewi Surinati ${ }^{1)}$ dan Muhammad Ramadhani Marfatah ${ }^{2)}$
}

\begin{abstract}
HYDRODYNAMICS EFFECT TO THE DISTRIBUTION OF THERMAL WASTE IN THE OCEAN. The ocean is a thermal waste disposal site derived from thermal power plants. The ecosystems and marine biota could be disrupted even massive damaged if this waste was disposed into the ocean without proper processing. All activities in the ocean need a well understanding of hydrodynamics to avoid or minimize any negative effects that may occur. It needs dispersion modeling of heat water prior to the construction of the power plant in order to reduce the impact of environmental damage.
\end{abstract}

\section{PENDAHULUAN}

Pencemaran lingkungan dibagi menjadi tiga jenis berdasarkan tempat terjadinya, yaitu pencemaran udara, pencemaran air dan pencemaran tanah. Di Indonesia, kerusakan lingkungan akibat pencemaran udara, air dan tanah sudah sangat kritis. Laut merupakan penampung segala sampah yang ada di muka bumi ini. Sampah yang berasal dari daratan mulai dari limbah domestik, limbah industri, serta limbah akibat transportasi jalur laut, baik itu yang sengaja maupun tidak disengaja. Paradigma tersebut telah menghapus konteks pengertian laut yang sesungguhnya bahwa laut merupakan sumberdaya yang kaya keanekaragaman, keunikan biota dan fenomena yang menyimpan berbagai misteri yang belum terpecahkan serta merupakan satu kesatuan ekosistem yang ada di dunia ini (Rochmad, 2006).

Salah satu limbah yang
mengkhawatikan bagi kelangsungan
kehidupan biota laut adalah limbah
panas. Buangan limbah panas terbesar
berasal dari pembangkit listrik. Apabila
limbah ini menyebar ke seluruh perairan
laut maka akan sangat membahayakan
bagi lingkungan laut dan hajat hidup
biota laut tentunya. Pembangkit listrik
merupakan salah satu teknologi untuk
pemenuhan kebutuhan energi bagi
manusia. Pembangkit listrik seperti
Pembangkit Listrik Tenaga Gas dan Uap
(PLTG/PLTU) merupakan suatu pusat
pembangkit listrik yang menggunakan
tenaga uap sebagai penggerak utama
turbin untuk menghasilkan listrik.
Selain memasok kebutuhan listrik,
juga menghasilkan limbah air buangan
(cooling water) yang langsung dibuang
secara sirkuler ke laut berupa limbah air
panas yang suhunya lebih tinggi daripada

\footnotetext{
1) Pusat Penelitian Oseanografi (P2O)-LIPI

2) Badan Informasi Geospasial (BIG)
} 
suhu air sebelum dipakai untuk pendingin (Hutomo \& Arinardi, 1992). Pembuangan limbah tersebut secara langsung ke laut tanpa melalui proses pendinginan kembali dapat menyebabkan pengaruh atau dampak, baik secara langsung maupun tidak langsung terhadap organisme yang hidup di dalamnya.

Regulasi pengelolaan buangan limbah air pendingin (cooling water) di Indonesia cukup mendapat perhatian, dibuktikan dengan dikeluarkannya beberapa peraturan yang menetapkan baku mutu parameter suhu. Demi menjaga kelestarian fungsi lingkungan laut, Menteri Negara Lingkungan Hidup telah melakukan upaya pengendalian terhadap kegiatan-kegiatan yang dapat mencemari atau merusak lingkungan laut. Salah satu upaya yang dilakukan adalah menetapkan baku mutu suhu air laut, serta kehidupan biota laut melalui Keputusan Menteri Lingkungan Hidup Nomor 51 Tahun 2004. Keputusan Menteri tersebut memberi batasan bagi industri yang beroperasi di wilayah pesisir agar tidak membuang limbah pada perairan melebihi ambang batas yang telah ditetapkan. Meskipun demikian, kebijakan ini menimbulkan masalah dalam implementasinya, mengingat aktivitas industri di wilayah pesisir selama ini menggunakan baku mutu yang ditetapkan oleh pemerintah daerah setempat yang bersifat sangat longgar sehingga beberapa industri telah melampaui baku mutu yang ditetapkan dalam keputusan tersebut. Untuk menangani masalah ini, pemerintah mengeluarkan Kepmen LH No.51 Tahun 2004 Pasal 5 (2) yang berbunyi "Dalam hal daerah telah menetapkan baku mutu air laut lebih longgar sebelum ditetapkannya keputusan ini, maka baku mutu air laut tersebut perlu disesuaikan dengan keputusan ini selambat-lambatnya dalam jangka waktu dua tahun sejak tanggal ditetapkannya keputusan ini”. Dalam hal ini pemerintah daerah harus segera melakukan evaluasi terhadap Surat Keputusan Menteri Negara Lingkungan Hidup tersebut (Kusuma, 2012).

\section{PENCEMARAN LIMBAH AIR PANAS (THERMAL WASTE POLLUTION)}

Suhu merupakan salah satu variabel lingkungan yang paling penting untuk keberlangsungan hidup, pertumbuhan, dan reproduksi organisme akuatik (Effendi, 2003). Suhu perairan tropis seperti di Indonesia dapat berubah, karena pengaruh lingkungan dalam jangka waktu tertentu. Suhu perairan dapat meningkat secara signifikan akibat aktivitas industri yang membuang limbah berupa air panas secara langsung ke laut, fenomena tersebut dikenal dengan pencemaran limbah air panas/thermal waste pollution (Huboyo \& Zaman, 2007).

Pencemaran limbah air panas (Thermal Waste Pollution) adalah masukan air dalam jumlah besar yang mengalami pemanasan dari satu atau sejumlah industri yang menggunakan sumber yang sama. Hal tersebut menyebabkan suhu airnya melebihi kondisi normalnya. Industri air pendingin menjadi sumber awal panas dimana 
pembangkit tenaga listrik menggunakan $80 \%$ air pendingin Huboyo \& Zaman, 2007).

Sejauh ini, jumlah terbesar dari buangan limbah air panas ke laut adalah dari pembangkit listrik (Gambar 1). Sekitar 20 juta meter kubik air pendingin dengan suhu $12{ }^{\circ} \mathrm{C}$ di atas suhu normal air laut, dibuang oleh pembangkit listrik tenaga minyak atau batu bara dengan tenaga $1000 \mathrm{MW}$ (Chin, 2006). Pengoperasian suatu instalasi pembangkit listrik tenaga termal, baik yang berbahan bakar batubara, minyak bumi maupun energi nuklir, umumnya menggunakan air laut sebagai pendingin. Air pendingin yang masuk kembali ke laut memiliki suhu di atas suhu normal air laut (Cahyana, 2015).

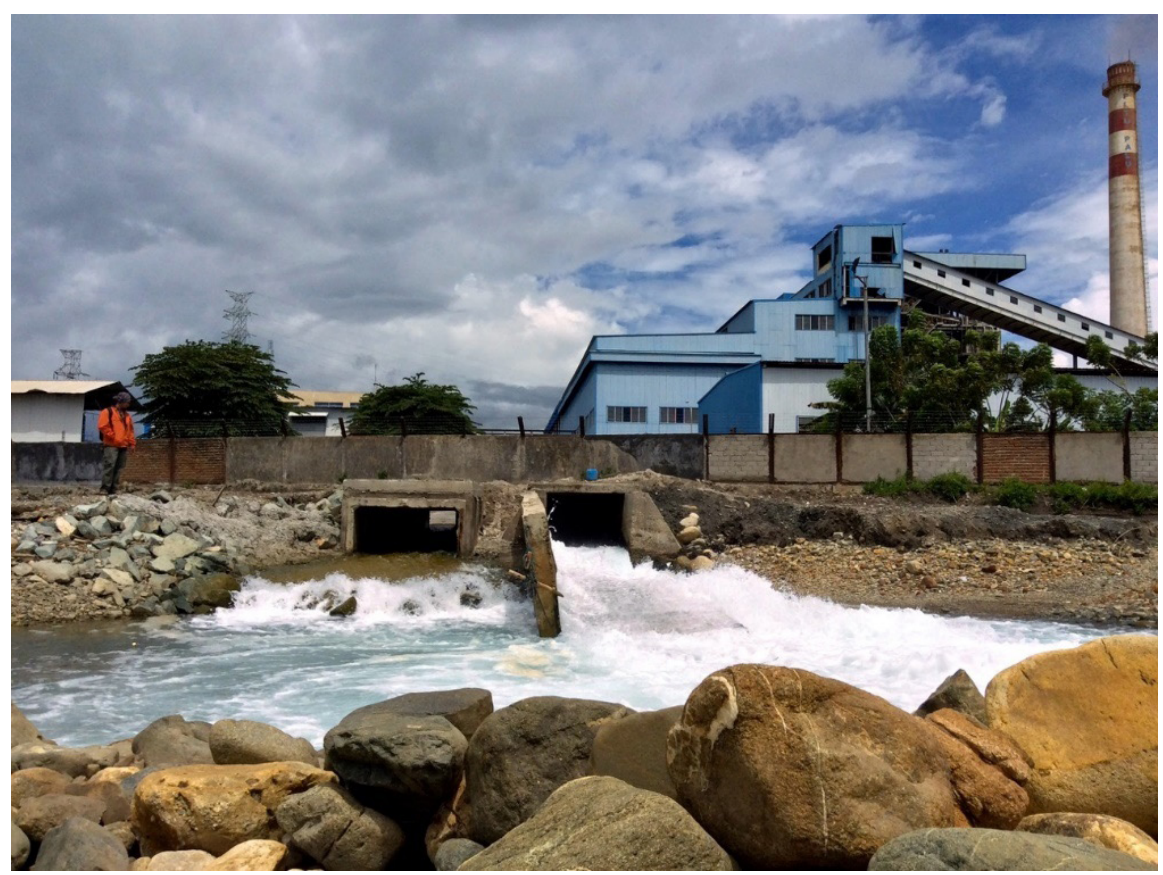

Gambar 1. Contoh pembuangan limbah air PLTU Mpanau (Rivai, 2016)

Limbah air panas dari instalasi pembangkit listrik biasanya dibuang secara langsung ke sungai sehingga meningkatkan suhu air dan menimbulkan pencemaran termal. Kenaikan suhu 10 derajat dapat mempercepat aktivitas metabolisme biota air menjadi dua kali dari biasanya. Masing-masing jenis biota air memiliki kecepatan metabolik yang berbeda, sehingga biota air hanya dapat hidup pada rentang suhu tertentu, dan berbeda untuk setiap kelompok biota. Populasi hewan air akan menurun pada suhu tinggi, dan hanya sedikit jenis hewan yang dapat hidup pada suhu di atas $40^{\circ} \mathrm{C}$. Tumbuhan lebih tahan terhadap kenaikan suhu. Kenaikan suhu air akan menurunkan prosentasi kelarutan oksigen. Pengaruh thermal waste pollution juga meningkatkan 
toksisitas zat kimia tertentu. Minyak dan petrokimia sejenis yang mencemari perairan akan membentuk lapisan tipis di permukaan air yang menghalangi pertukaran oksigen dalam air dengan di atmosfer. Hal ini menyebabkan penurunan kandungan oksigen dalam air. Perubahan suhu yang terjadi kemungkinan dapat memengaruhi salinitas baik terhadap air limbah pendingin sendiri maupun terhadap perairan sepanjang penyebaran air limbah. Hal itu disebabkan adanya proses percampuran antara air limbah dengan badan air di titik pembuangan, dan sekitarnya (Huboyo \& Zaman, 2007). Pembuangan air limbah secara langsung ke badan air sekitarnya tanpa melalui proses pendinginan dapat menyebabkan perubahan kualitas perairan, baik langsung maupun tidak langsung. Selain itu, dapat berpengaruh terhadap organisme yang hidup di dalam badan air (Trihadiningrum \& Tjondronegoro, 1998).

Air menjadi satu kebutuhan penting yang digunakan pada setiap pembangkit tenaga listrik yang memakai uap air sebagai media kerjanya. Pengadaan dan kualitasnya menjadi satu hal yang sangat dijaga di setiap PLTU. Air juga dimanfaatkan untuk kebutuhan pendinginan, perawatan kebersihan, mengontrol polutan, dan sebagai media kerja untuk siklus uap air. Treatment air yang baik dapat mencegah terbentuknya kerak dan korosi pada sistem pembangkit listrik, yang bekerja pada siklus uap air tekanan tinggi demi menghindari kerugian ekonomi karena penurunan kemampuan produksi dan kenaikan biaya produksi. Air limbah dan bahan buangan industri akan mengubah $\mathrm{pH}$ air yang akhirnya akan mengganggu kehidupan biota akuatik. Sebagian besar biota akuatik sensitif terhadap $\mathrm{pH}$ dan menyukai $\mathrm{pH}$ antara 7-8,5. Nilai $\mathrm{pH}$ sangat memengaruhi proses biokimiawi perairan, misalnya proses nitrifikasi akan berakhir pada $\mathrm{pH}$ yang rendah (Sumantri, 2010).

Pada PLTU, klorin digunakan untuk membunuh biota laut, agar biota tersebut tidak menyumbat saluran air pendingin. Air pendingin dari air laut diperlukan dalam jumlah besar, yaitu beberapa ton per detik. Air laut ini mengandung berbagai bakteri (mikroorganisme) yang dapat tumbuh dan menempel pada saluran, sehingga mengurangi efektivitas dan efisiensi sistem pendinginan PLTU. Tindakan penyuntikan gas klor $\left(\mathrm{Cl}_{2}\right)$ ke dalam saluran air, dilakukan untuk membunuh mikroorganisme tersebut. Penyuntikan gas klor ini tidak dilakukan secara kontinu, hal ini untuk mencegah terjadinya kekebalan mikroorganisme (Marsudi, 2011).

Laut merupakan salah satu tempat pembuangan limbah panas dari pembangkit listrik tenaga panas. Jika limbah panas yang dibuang menuju laut tidak sesuai dengan suhu normal laut, maka kehidupan biota laut disekitar pembuangan limbah panas akan terganggu (Fudlailah et al., 2011). Limbah yang mempunyai suhu panas akan mengganggu pertumbuhan biota tertentu. Suhu yang dikeluarkan suatu limbah cair harus merupakan suhu alami. Suhu 
mempengaruhi aktivitas kimiawi dan biologis. Pada suhu tinggi pengentalan cairan akan berkurang dan mengurangi sedimentasi. Tingkat zat oksidasi lebih besar pada suhu tinggi dan pembusukan jarang terjadi pada suhu rendah (Ginting, 2007).

Perairan yang menerima air pendingin, lambat laun akan mengalami kenaikan suhu akibat pembuangan air pendingin (Hutomo \& Arinardi, 1992). Tindakan pengawasan perairan perlu dilakukan dengan cara monitoring untuk mengetahui jenis polutan dan bagaimana penyebaran polutannya (Kartini \& Danusaputro, 2005). Perubahan suhu dapat menyebabkan perubahan keseimbangan dinamis oksigen dalam air yang kompleks yang berhubungan dengan reaerasi atmosfir, produksi fotosintesis, difusi, percampuran dan sebagainya. Oleh karena itu, perlu adanya penelitian terhadap penyebaran polutan limbah panas pada daerah yang terkontaminasi (Huboyo \& Zaman, 2007).

Transpor polutan limbah panas terjadi karena proses adveksi, difusi, konduksi, konveksi, serta turbulensi laut. Pertukaran gas udara-laut yang disinyalir berpengaruh besar pada perubahan air laut akibat adanya limbah cair, pengaruh distribusi Suspended Particulate Matter (SPM) air laut yang mengalami pengendapan (sinking), dan deposisi partikel selanjutnya sebagai sedimen dan melihat degradasi dalam air laut (Anonymous, 2014).

Proses adveksi dan difusi terjadi pada badan air laut, sedangkan proses konduksi dan konveksi terjadi pada batas air dan udara. Biasanya permukaan laut lebih panas dari udara di atasnya, sehingga terdapat sejumlah panas yang hilang dari laut melalui proses konduksi. Dengan kata lain, bahwa luas sebaran polutan panas dari kanal pendingin tergantung pada beberapa faktor, yaitu volume air limbah, suhu air limbah, suhu ambien air laut dan sirkulasi air laut di lokasi masuknya air limbah ke laut (Cahyana, 2015).

Untuk mengetahui sebaran air limbah ke badan air sekitarnya perlu adanya suatu sistem yang informatif. Penelitian-penelitian sebelumnya hanya menghasilkan database yang kurang informatif untuk program mengenai kualitas lingkungan di masa yang akan datang (Bhattacharya et al., 2003). Sistem yang informatif akan memudahkan dalam analisis kondisi lingkungan yang terjadi khususnya mengenai kondisi penyebaran limbah air panas dan kemungkinan perubahan salinitasnya.

\section{HIDRODINAMIKA LAUT}

Definisi hidrodinamika adalah studi ilmiah tentang gerak fluida, khususnya zat cair incompressible yang dipengaruhi oleh gaya internal dan eksternal. Dalam hidrodinamika laut, gaya yang terpenting adalah gaya gravitasi, gesekan dan Coriolis. Gaya gravitasi merupakan gaya yang dominan dalam hidrodinamika. Perubahan gravitasi yang diakibatkan oleh gerakan matahari dan bulan relatif terhadap bumi, menyebabkan terjadinya pasang surut, 
arus dan pencampuran. Gaya gesekan adalah gaya yang bekerja pada dua buah permukaan yang saling bersentuhan dan terjadi gerak relatif antara keduanya. Gaya adalah gaya semu yang dominan dan memengaruhi gerak dalam sistem koordinat yang disesuaikan terhadap bumi. Efek Coriolis disebabkan oleh rotasi bumi dan menentukan arah rotasi dari massa air, akibatnya arus berputar searah jarum jam di bumi bagian selatan, dan berlawanan arah jarum jam di bumi bagian utara (Stewart, 2006).

Segala sesuatu yang terjadi di suatu perairan membutuhkan adanya pemahaman hidrodinamika, hal ini untuk menghindari atau meminimalisasi efek negatif yang dapat terjadi di perairan, salah satunya adalah masalah pencemaran limbah cair panas. Penyelesaian permasalahan tersebut dapat dilakukan dengan cara yang beragam, seperti pemodelan fisik dan model hidrodinamika. Permodelan fisik membutuhkan banyak biaya, waktu, dan ruang yang cukup luas, serta tidak fleksibel dalam membuat berbagai atau skenario yang dibutuhkan. Salah satu kajian yang banyak digunakan adalah dengan menggunakan model hidrodinamika, karena permodelan ini lebih menghemat biaya, tidak membutuhkan banyak tempat untuk dapat memodelkan, lebih efisien saat melakukan tahapan-tahapan pemodelan dan dapat dengan mudah melakukan berbagai macam skenario untuk perbandingan hasil dan kajian yang dibutuhkan (Sianturi et al., 2013).

Pemodelan hidrodinamika memerlukan data batimetri. Batimetri merupakan salah satu faktor penting dalam proses distribusi limbah panas. Batimetri juga berhubungan dengan kecepatan dan arah arus, pasang surut dan sedimen. Selain itu, bentuk batimetri juga memengaruhi hasil dari model yang dilakukan dimana terdapat faktor kekasaran dasar (resistance) yang juga digunakan dalam inputan model (Sianturi et al., 2013).

Simulasi untuk penyebaran limbah panas dilakukan dengan menambahkan data pasang perbani dan purnama, serta surut saat perbani dan purnama. Oleh karena itu, perlu survey hidrooseanografi untuk mendapatkan gambaran mengenai kondisi pasang surut perairan setempat. Pasang surut merupakan salah satu faktor yang memengaruhi rambatan panas di perairan laut. Nilai elevasi tertinggi terjadi saat pasang tertinggi, yaitu saat Pasang Purnama, sedangkan elevasi terendah adalah pada saat Pasang Perbani (Anonymous, 2014). Hal ini mengindikasikan bahwa tinggi rendahnya elevasi muka air laut, akan berpengaruh pada angka kenaikan suhu air laut. Pada saat terjadi surut, kekuatan debit dari air limbah lebih mendominasi dibandingkan kekuatan pasang-surut air laut (Fudlailah et al., 2011).

Hasil perhitungan luasan daerah yang terdampak kenaikan suhu air laut tertinggi dari beberapa penelitian menunjukkan bahwa luasan terdampak pada saat musim penghujan lebih besar dibandingkan dengan kondisi musim kemarau. Meskipun kenaikan suhu tertinggi di lokasi yang tegak lurus 
dengan mulut kanal terjadi pada keadaan surut purnama penghujan, namun pada keadaan pasang purnama penghujan luasan area terdampak kenaikan suhu air laut $>1.5-2^{\circ} \mathrm{C}$ lebih besar. Luasan area terdampak terendah adalah pada saat pasang purnama kemarau (Fudlailah et al., 2011).

\section{PEMODELAN SEBARAN LIMBAH AIR PANAS}

Pemodelan penyebaran limbah air panas menunjukkan bahwa sebaran kenaikan suhu air laut akan meluas, seiring dengan pertambahan kenaikan suhu limbah panas (air bahang). Pada musim penghujan dan kemarau, menunjukkan kenaikan suhu air laut lebih meluas pada kondisi surut. Pemodelan penyebaran limbah panas ini dapat digunakan untuk memperkirakan valuasi kerugian ekonomi akibat kerusakan ekosistem terumbu karang, dengan memperhitungkan luasan daerah terdampak kenaikan suhu air laut dan nilai ekonomi ekosistem terumbu karang. Pemodelan penyebaran limbah panas ini secara umum dapat digunakan untuk menilai dampak kerusakan lingkungan, akibat buangan limbah panas (Fudlailah et al., 2011).

\section{Menurut Laporan Pengkajian Limbah Cair PLTU Molotabu} (Anonymous, 2014) faktor-faktor yang terkait dan relevan dengan pembuangan air ke laut tergantung pada beberapa hal yaitu: 1. karakteristik air limbah (termasuk kuantitas debit dan kualitas limbah yang dihasilkan terkait dengan karakteristik fisik, seperti suhu air limbah, karakteristik biologi terutama kelimpahan biota laut serta karakteristik kimia terkait dengan kandungan zat dan logam berbahaya dalam air limbah tersebut); 2. kondisi oseanografi meliputi arus, gelombang dan pasang surut; 3 . kondisi meteorologi, terutama angin; 4. sirkulasi massa air tempat pembuangan limbah.

Data input yang digunakan dalam pemodelan meliputi data hidrodinamika (pasang surut, batimetri, arah dan kecepatan angin) musim barat dan musim timur, suhu ambien perairan serta data gradien suhu $(\Delta \mathrm{T})$ yang berasal dari buangan air pendingin (cooling water). Data validasi merupakan data yang diperoleh berdasarkan pengamatan langsung di lapangan. Data tersebut digunakan untuk melihat pola kesesuaian dari data input model terhadap kondisi perairan sesungguhnya. Data yang digunakan untuk validasi model adalah data pasang surut selama setahun dan merupakan hasil pengukuran oleh Badan Koordinasi Survei dan Permetaan Nasional (BAKOSURTANAL) dengan interval pengukuran perjam. Data hidrodinamika digunakan untuk melihat kondisi hidrodinamika, antara lain berupa arah dan kecepatan arus (U dan V), serta perubahan tinggi muka air laut (surface elevation) terhadap mean sea level (MSL) (Kusuma, 2012).

Simulasi model merupakan hasil akhir yang telah diproses (running) selama 15 hari. Hasil akhir tersebut dicuplik berdasarkan pengaruh angin musim, serta mempertimbangkan kondisi ekstrim 
pasang surut setempat (saat menuju surut, surut terendah, menuju pasang, serta pasang tertinggi). Waktu pencuplikan ditentukan berdasarkan data pasang surut lapang yang diwakili bulan Januari (musim barat), dan bulan Juli (musim timur). Hasil pencuplikan tersebut akan digunakan untuk mengetahui distribusi pola arus, serta sejauh mana pengaruh buangan limbah air pendingin dalam rentang waktu 15 hari. Hasil akhir yang ditampilkan berupa distribusi pola arus berdasarkan kondisi pasang surut tiap musimnya, serta sebaran maksimum dari limbah buangan air pendingin (cooling water) di lokasi kajian pemodelan (Kusuma, 2012).
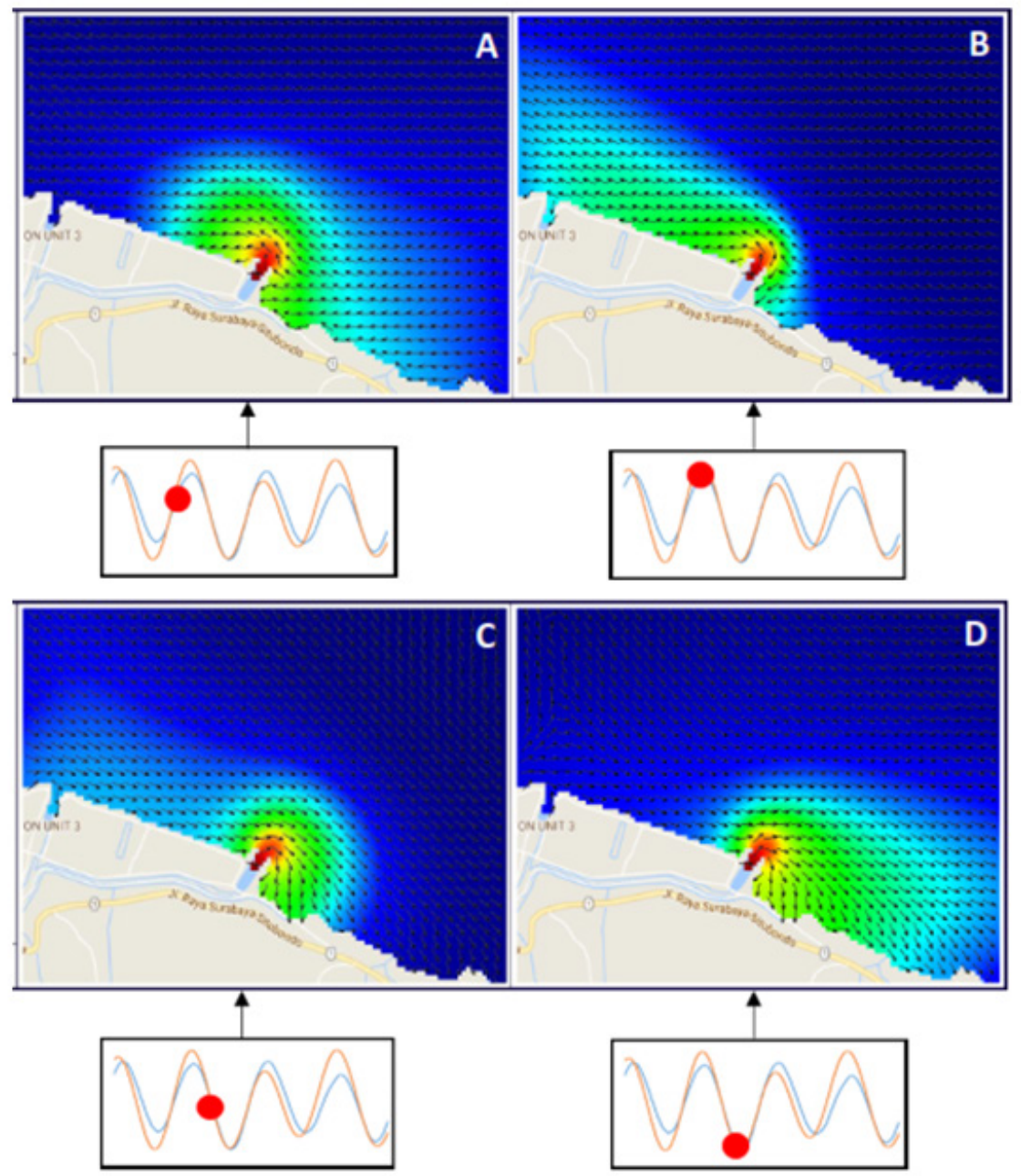

Gambar 2. Contoh hasil pemodelan (A) Sebaran limbah air panas secara horizontal menuju pasang, (B) pada saat pasang maksimum, (C) pada saat menuju surut, dan (D) pada saat surut maksimum (Fikri, 2018). 
Model sebaran dispersi termal dibangun dengan skenario di lokasi yang memiliki sumber buangan limbah air panas menuju perairan dan sekitarnya (Gambar 2). Penentuan domain model mencakup lokasi outlet PLTGU, serta lokasi pengukuran pasang surut. Pasang surut merupakan salah satu parameter yang dapat digunakan untuk melakukan validasi model. Validasi data pada model ini ditunjukkan dengan grafik, serta tabulasi konstanta harmonik pasut, baik pada musim barat maupun musim timur. Arus merupakan fenomena naik turunnya massa air laut yang dapat dibangkitkan oleh berbagai gaya baik secara eksternal maupun internal. Pergerakan massa air atau arus ini merupakan media yang mampu memindahkan bahang dari sumbernya ke tempat lain (Nurjaya \& Surbakti, 2010).

\section{DAMPAK DAN SOLUSI PENCEMARAN LIMBAH AIR PANAS}

Pendinginan buangan limbah panas biasanya terjadi karena tercampur dengan air laut. Area yang terpengaruh oleh limbah ini dibatasi oleh plume air panas, dan kecepatan arus lingkungan di sekitarnya. Meskipun demikian, arah arus yang membawa plume dapat berubah, karena arus pasang surut dan dengan demikian total area terpengaruh akan menjadi lebih besar daripada yang terlihat pertama kali. Selain itu, pembuangan air bekas pendingin tersebut, juga menyebabkan pemerataan peningkatan kadar padatan terlarut yang mengakibatkan terjadinya sedimen di air laut pada daerah sekitar pembuangan. Hal tersebut terjadi karena sifat pembuangan yang berlangsung terus menerus, sehingga sifat keberadaan padatan terlarut di air laut cenderung tidak berbalik (tetap padat, sulit larut kembali, dan cenderung untuk membentuk sedimen). Dampak dari limbah air panas dengan limbah yang lain sangat sulit dibedakan. Hal ini disebabkan oleh air pendingin yang umumnya telah diolah terkadang diselingi dengan pemberian klorin untuk menghalangi pengendapan organisme pada sistem heat-exchange. Scouring yang terjadi di dasar laut disebabkan oleh aliran plume yang dapat merubah aliran alami lingkungan laut dan juga akan memengaruhi biota laut.

Luas pengaruh limbah panas tergantung pada beberapa faktor yaitu volume air limbah, suhu air limbah, suhu air tempat pembuangan limbah, dan arus atau sirkulasi massa air tempat pembuangan limbah panas. Limbah panas berpengaruh terhadap perairan, baik fisik, kimia maupun biologi. Secara fisik berpengaruh terhadap densitas, viskositas, tekanan uap, dan kelarutan (Huboyo \& Zaman, 2007). Pengaruh terhadap densitas dan viskositas berdasarkan hukum Stokes tentang pengendapan padatan dalam medium nonturbulen. Efek suhu mempunyai dampak spesifik, sehingga perlu dipelajari efeknya terhadap spesies lokal yang penting. Tingkat oksigen dan salinitas turut memengaruhi efek tersebut. Penurunan oksigen terlarut dan kenaikan laju metabolisme dapat berkombinasi yang menyebabkan lingkungan kurang 
sesuai bagi kehidupan ikan (Sunarsih, 1996).

Suhu air yang lebih hangat menyebabkan organisme perairan mengalami peningkatan laju respirasi dan peningkatan konsumsi oksigen, serta lebih mudah terkena penyakit, parasit dan bahan kimia beracun. Untuk meminimalisir efek panas yang berlebihan terhadap ekosistem perairan adalah melalui pengurangan terhadap penggunaan dan pembuangan listrik. Minimalisir efek panas juga dapat dilakukan dengan pembatasan jumlah buangan air panas ke dalam badan air yang sama, control dengan difusi, mentransfer panas dari air ke atmosfir dengan tower pendingin basah atau kering, pembuangan air panas kedalam kolam yang dangkal atau kanal untuk pendinginan dan memanfaatkan kembali (reuse) sebagai air pendingin (cooling water) (Huboyo \& Zaman, 2007).

\section{PENUTUP}

Buangan limbah panas dari pendingin mesin pembangkit tenaga listrik ke perairan laut secara kontinyu di suatu tempat, dan tidak mempertimbangkan kondisi perairan dan cuaca, serta iklim dapat berdampak negatif terhadap kehidupan organisme di habitat perairannya. Hal ini dapat diminimalisasi atau bahkan tidak akan berdampak sama sekali, jika dilakukan suatu usaha untuk mengatur buangan limbah air panas dengan manajemen yang tepat dan benar. Sistem pembuangan limbah air panas yang ramah lingkungan diperlukan untuk menjaga kelangsungan kehidupan ekosistem pesisir. Pola sebaran limbah cair di perairan dipengaruhi oleh pergerakan massa air di lokasi tersebut. Kecepatan pergerakan massa air yang semakin besar akan menyebabkan pergerakan limbah cair di perairan yang semakin luas. Oleh karena itu diperlukan pemahaman hidrodinamika yang baik untuk melakukan pemodelan penyebaran limbah panas ini dalam rangka pengurangan dampak kerusakan lingkungan.

\section{DAFTAR PUSTAKA}

Anonymous. 2014. Pembuangan Limbah Cair PLTU Molotabu 2 X 12 MW ke Laut oleh PT. Tenaga Listrik Gorontalo. Laporan Pengkajian. PT. Tenaga Listrik Gorontalo. 22 hal.

Bhattacharya, B., S. K. Sarkar, and R. Das. 2003. Seasional Variation And Inherent Variability of Selenium In Marine Biota of a Tropica Wetland Ecosystem:Implication for Bioindicator Species. J. Eco. Indicators. 2 (4): 311-402.

Cahyana, C. 2015. Model Sebaran Panas Air Kanal Pendingin Instalasi Pembangkit Listrik ke Badan Air Laut. Dalam: Prosiding Seminar Nasional Teknologi Limbah Radioaktif-BATAN. 293-302. ISSN 1410-6086.

Chin, D.A. 2006. Water-Quality Engineering in Natural Systems. John Wiley \& Sons. $592 \mathrm{pp}$. 
Effendi, H. 2003. Telaah Kualitas Air bagi Pengelolaan Sumberdaya dan Lingkungan Perairan, Penerbit Kanisius, Yogyakarta. 256 hal.

Fikri, M.Y. 2018. Studi Sebaran Limbah Air Panas PLTU Paiton dari Observasi dan Pemodelan Numerik. Skripsi. Institute Pertanian Bogor (IPB). Bogor: 48 hal.

Fudlailah, P., Mukhtasor dan M. Zikra. 2011. Pemodelan Penyebaran Limbah Panas di Wilayah Pesisir (Studi Kasus Outfall PLTU Paiton). http://digilib. its.ac.id/public/ITS-paper31211-4309100011-paper.pdf. Diakses pada tanggal 7 Januari 2017.

Ginting, P. 2007. Sistem Pengolahan Lingkungan dan Limbah Industri. Bandung: Yrama Widya: 224 hal.

Huboyo, H. S. dan B. Zaman. 2007. Analisis Sebaran Temperatur dan Salinitas Air Limbah PLTU-PLTGU Berdasarkan Sistem Pemetaaan Spasial (Studi Kasus: PLTU-PLTGU Tambak Lorok Semarang). Jurnal Presipitasi 3 (2): 40-45.

Hutomo, M. dan O.H. Arinardi. 1992. Dampak Pembangkit Tenaga Listrik (Terutama Limbah Termal) terhadap Ekosistem Akuatik. Oseana, XVII (4): 135-158.
Kartini dan H. Danusaputro. 2005. Estimasi Penyebaran Polutan Dengan Metode Self Potential (Studi Kasus TPA Jatibarang, Kecamatan Mijen, Semarang). Berkala Fisika, 8(1): 27-32.

Kusuma, I. P. M. A. 2012. Pemodelan Dispersi Termal Air Buangan (Cooling Water) Pembangkit Listrik Tenaga Gas dan Uap (PLTGU) di Perairan Pantai Pemaron, Singaraja-Bali. Skripsi. Departemen Ilmu Dan Teknologi Kelautan Fakultas Perikanan Dan Ilmu Kelautan Institut Pertanian Bogor. Bogor: 68 hal.

Marsudi, D. 2005. Pembangkitan Energi Listrik, Erlangga, Jakarta. 239 hal.

Mukhtasor, 2007. Pencemaran Pesisir dan Laut, Cetakan Pertama Pradnya Paramita, Jakarta. 322 hal.

Nurjaya, I.W. dan H. Surbakti. 2010. Model Dispensi Bahan Hasil Buangan Air Proses Pendinginan PLTGU Cilegon CCPP ke Perairan Pantai Margasari di Sisi Barat Teluk Banten, E-Jurnal Ilmu Teknologi Kelautan Tropis, 2 (1) : 31-49.

Rivai, M. 2016. Apakah PLTU Mpanau Berdampak pada Hancurnya Budidaya Rumput Laut Teluk Palu?. http://www.mongabay. co.id. Diakses Tanggal 6 September 2017. 
Rochmad, S. 2006. Ruang Lingkup Pencemaran. Modul Pencemaran Lingkungan. Universitas Terbuka Repository: 38 hal.

Sianturi, O. R., S. Widada, I. B. Prasetyawan dan F. Novico. 2013. Pemodelan Hidrodinamika Sederhana Berdasarkan Data HidroOseanografi Lapangan di Teluk Lampung. Jurnal Oseanografi, 2(3): 299-309.

Stewart, R. H. 2006. Introduction to Physical Oceanography, Department of Oceanography. Texas A\&M University. Texas: $343 \mathrm{pp}$.
Sumantri, A. 2010. Kesehatan Lingkungan. Kencana Prenada Media Group. Jakarta: 346 hal.

Sunarsih. 1997. Model pencemaran limbah air panas. Pembangkit Listrik Tenaga Uap. Tambak Lorok di Kolam Pelabuhan Tanjung Emas, Semarang. Tesis. Universitas Indonesia 210 hal.

Trihadiningrum, Y. dan Tjondronegoro. 1998. Makroinvertebrata Sebagai Bioindikator Pencemaran Badan Air Tawar di Indonesia Siapkah Kita?. Lingkungan dan Pembangunan 18 (1): 45-60. 